\author{
Bartosz Szczechowicz \\ Paweł Stelmach \\ Akademia Wychowania Fizycznego w Krakowie \\ Katedra Polityki Turystycznej \\ Zakład Ekonomii i Zarządzania \\ bartosz.szczechowicz@awf.krakow.pl \\ pawel.stelmach@awf.krakow.pl
}

\title{
EWOLUCJA PROGRAMÓW ORAZ METOD NAUCZANIA Z ZAKRESU GOSPODARCZYCH ASPEKTÓW TURYSTYKI I REKREACJI W AKADEMII WYCHOWANIA FIZYCZNEGO W KRAKOWIE
}

\begin{abstract}
Abstrakt: Celem autorów artykułu jest odpowiedź na pytanie: jakie działania mogą podejmować uczelnie o profilu nieekonomicznym na rzecz doskonalenia programów nauczania przedmiotów modułu ekonomicznego i metod ich realizacji? Wykorzystano techniki analizy literatury, obserwacji uczestniczącej oraz statystyki opisowej w oparciu o pierwotny zbiór 430 prac zaliczeniowych z przedmiotu "Marketing usług turystycznych i rekreacyjnych" z lat 2014/2015, 2015/2016 i 2016/2017 w ramach studium przypadku krakowskiej AWF. Przyjęcie orientacji na studenta jako długookresowego partnera w procesie wymiany informacji, w myśl koncepcji marketingu relacji, przyczynia się do intensyfikacji procesu dydaktycznego ukierunkowanego na poszerzanie wiedzy o rzeczywistości gospodarczej.
\end{abstract}

Słowa kluczowe: dydaktyka ekonomii, dydaktyka marketingu, edukacja akademicka, szkolnictwo wyższe, szkoły wyższe, informacja zwrotna.

\section{WPROWADZENIE}

Tradycja kształcenia na kierunku turystyka i rekreacja w zakresie nauk ekonomicznych zakłada dość obszerną prezentację podstawowej wiedzy z zakresu poszczególnych dyscyplin wskazanych nauk - ekonomii, zarządzania i marketingu, finansów - a następnie jej odniesienie do specyfiki branży turystycznej i rekreacyjnej jako dziedziny gospodarowania. O ile jednak taki układ treści, rozgraniczający elementy zasadnicze od swoistych, jest typowy dla uczelni o profilu ekonomicznym, to nie zawsze jest możliwy do realizacji na uczelniach, dla których nauki ekonomiczne nie są podstawową, lecz uzupełniającą dziedziną wiedzy.

Celem niniejszej pracy jest zatem odpowiedź na pytanie: jakie działania mogą podejmować wspomniane uczelnie na rzecz doskonalenia programów nauczania przedmiotów modułu ekonomicznego i metod ich realizacji? Pytanie to postawiono przy założeniu, że owe działania mogłyby poprawić efektywność nauczania, a zarazem podkreślić specy- cyficzny charakter tych uczelni - jako łączących elementy kształcenia ogólnego z zawodowym.

Uszczegółowienie tej kwestii wyraża zestaw pytań badawczych:

1. Jak dalece uwarunkowania kształcenia na uczelni o profilu innym niż ekonomiczny determinują cele nauczania przedmiotów z zakresu nauk ekonomicznych?

2. Jakiego typu efekty kształcenia dla przedmiotów z zakresu nauk ekonomicznych - odwołujące się do wiedzy, umiejętności i kompetencji społecznych - można i należy stawiać przed studentami uczelni o profilu innym niż ekonomiczny?

3. Czy integracja treści kształcenia przedmiotów z zakresu nauk ekonomicznych może poprawić jakość kształcenia?

4. Czy możliwe i efektywne jest uzgodnienie zbioru metod dydaktycznych w ramach całego modułu przedmiotów z zakresu nauk ekonomicznych? 
Odpowiedzi na te pytania zostaną udzielone na podstawie doświadczeń płynących $\mathrm{z}$ wieloletniego kształcenia na wspomnianym kierunku w krakowskiej Akademii Wychowania Fizycznego. Zastosowaną metodę można określić jako studium przypadku, które obrazuje nieustanne działania zespołu nauczycieli na rzecz optymalizowania sposobu nauczania, w tym doskonalenia programów przedmiotów i sposobów ich realizacji - w odpowiedzi na zmieniające się uwarunkowania zewnętrzne funkcjonowania szkoły wyższej, obserwację osiąganych efektów kształcenia i informacje zwrotne pozyskiwane od studentów.

\section{OGÓLNE UWARUNKOWANIA KSZTAŁCENIA W ZAKRESIE NAUK EKONOMICZNYCH NA KIERUNKU „TURYSTYKA I REKREACJA”}

Świadomość warunków, w jakich przebiega proces kształcenia w każdej szkole wyższej jest niezbędna do zrozumienia roli poszczególnych przedmiotów w programie studiów danego kierunku, a także właściwego sformułowania stawianych przed nimi celów i efektów, a dalej - skonstruowania programów i doboru metod kształcenia (por. KUPISIEWICZ 2012). Warunki te wyznaczane są przede wszystkim przez otoczenie zewnętrzne, w tym zwłaszcza instytucje formalne (normy prawne) regulujące funkcjonowanie szkół wyższych. Ostatnia dekada przyniosła w Polsce zasadniczą zmianę tych warunków. Porzucono bowiem obowiązujące na poszczególnych kierunkach standardy kształcenia (Rozporzadzenie MNiSW 2007), wprowadzając $w$ to miejsce założenia deklaracji bolońskiej. Ta ostatnia nadała szkołom wyższym możliwość modyfikowania dotychczasowych celów kształcenia i swobodnego kształtowania programów nauczania, a także kreowania nowych kierunków studiów.

Zgodnie z przywołanymi standardami kształcenia, obowiązującymi dla kierunku "turystyka i rekreacja" w latach 2007-2012, absolwent studiów I stopnia winien - w interesującym nas zakresie - mieć ogólną wiedzę z obszaru nauk ekonomicznych oraz umiejętności podejmowania przedsięwzięć $\mathrm{w}$ sferze turystyki i rekreacji. Powinien posiadać umiejętność m.in. przygotowywania oferty turystycznej i rekreacyjnej dla różnych grup odbiorców (w ramach prowadzenia własnej działalności gospodarczej oraz wykonywania pracy najemnej w przedsiębiorstwach), ale także pracy w organizacjach społecznych lub publicznych (Standardy... 2007). Podane kwalifikacje student nabywał realizując kształcenie $\mathrm{w}$ grupie treści podstawowych i treści kierunkowych. W ramach pierwszych wskazano takie - jak to określono - „składniki treści kształ- cenia”, jak „Ekonomia” i „Zarządzanie”, a w ramach drugich - „Ekonomika turystyki i rekreacji"; przypisano im zarazem minimalną liczbę godzin do realizacji, a także treści i zakładane efekty kształcenia (Standardy... 2007). Także w ramach innych przedmiotów obecne były pewne treści kształcenia związane $\mathrm{z}$ aspektami gospodarczymi - co dotyczy zarówno studiów I, jak i II stopnia.

Absolwent studiów II stopnia winien być ponadto przygotowany do podejmowania i prowadzenia samodzielnej działalności menadżerskiej w sferze turystyki i rekreacji, co oznacza - jak wyjaśniono - zdolność do samodzielnego podejmowania decyzji zmierzających do rozwiązywania problemów napotykanych w działalności gospodarczej, w tym także do zarządzania przedsiębiorstwami turystycznymi i rekreacyjnymi, tudzież kreatywnej pracy $\mathrm{w}$ tego typu przedsiębiorstwach, a także innych organizacjach przynależących do sfery turystyki i rekreacji (Standardy... 2007). Także te kwalifikacje miał nabywać $\mathrm{w}$ ramach nauczania treści podstawowych i kierunkowych, przy czym interesujące nas składniki treści kształcenia zawarte były tylko $\mathrm{w}$ drugiej grupie. Należały do nich: "Marketing usług turystycznych i rekreacyjnych", "Produkt turystyczny", "Zarządzanie przedsiębiorstwem turystycznym i rekreacyjnym" (Standardy... 2007).

W przedstawionym stanie rzeczy - przypomnijmy, że obowiązującym do 2012 r. - zwracają uwagę:

- wyraźne rozgraniczenie celów kształcenia w ramach I i II stopnia studiów (przygotowanie do pracy w sferze turystyki i rekreacji na podstawie ogólnej wiedzy ekonomicznej versus działalność menadżerska realizowana $\mathrm{w}$ ramach własnego przedsiębiorstwa lub pracy najemnej);

- podział treści kształcenia na podstawowe i kierunkowe (zapoznanie studentów z ogólną wiedzą ekonomiczną, a dopiero $w$ ślad za tym - odniesienie tej ogólnej wiedzy do sfery turystyki i rekreacji);

- znaczny zasób zagadnień składający się na treści poszczególnych przedmiotów (każdy z przedmiotów stanowił względnie samodzielną całość, a jego program obejmował dość szeroki zasób wiadomości związanych $\mathrm{z}$ reprezentowaną dziedziną nauki);

- brak wyraźnego rozgraniczenia pewnych treści między poszczególne przedmioty (dotyczy to np. konceptualizacji i planowania produktu).

Wraz z odejściem od standardów kształcenia zaczęto $w$ Polsce wdrażać $\mathrm{w}$ życie założenia deklaracji bolońskiej, podpisanej już w 1999 r. Nie prezentując w tym miejscu wszystkich celów strategicznych oraz założeń procesu bolońskiego odnotujmy tylko, że proces boloński zakłada wprowadzenie tzw. ram 
kwalifikacji, które - wyrażając w języku efektów kształcenia kwalifikacje nabywane $\mathrm{w}$ ramach oświaty i szkolnictwa wyższego, a także poza nimi - pozwalałyby na porównywanie kwalifikacji zdobywanych przez różne osoby, także $\mathrm{w}$ środowisku ogólnoeuropejskim (CHMIELECKA 2013). Wspomniane efekty, w Polsce wyrażone w Polskiej ramie kwalifikacji (2016), opisywane są w kategoriach wiedzy, umiejętności i kompetencji społecznych: co dotyczy zarówno efektów kierunkowych, jak i przedmiotowych, przy czym pierwsze winny być przyporządkowane do jednego z ośmiu obszarów kształcenia; obszary te, co do zasady, odpowiadają dziedzinom nauki'. Jakkolwiek dydaktyka akademicka nawet $\mathrm{w}$ wydaniu uniwersyteckim już wcześniej zawierała element kształcenia zawodowego, to wdrożenie założeń deklaracji bolońskiej wyraźnie zmieniło dotychczasowe proporcje między kształceniem ogólnym i zawodowym, na korzyść tego drugiego (WRÓBLEWSKA 2008).

Przedstawiony sposób organizacji szkolnictwa wyższego daje uczelniom dużą autonomię $\mathrm{w}$ tworzeniu programów kształcenia (CHMIELECKA 2013). Podmioty te nie muszą ograniczać swej oferty tylko do ściśle określonych kierunków studiów, o przypisanym im programie, lecz moga te kierunki oraz programy ich realizacji dowolnie kształtować. Wydaje się, że odejście od standardów kształcenia pozwoliło uwypuklić specyfikę poszczególnych szkół wyższych. Dla studiów przygotowujących do pracy w sferze turystyki i rekreacji skutkowało to pogłębieniem specjalizacji kształcenia (obok tradycyjnego kierunku "turystyka i rekreacja" szkoły wyższe zapoczątkowały kształcenie na kierunkach pokrewnych, takich jak np. gospodarka turystyczna) oraz zróżnicowaniem profilów studiów - co dało się zauważyć zwłaszcza między studiami realizowanymi $w$ akademiach wychowania fizycznego oraz uniwersytetach i akademiach ekonomicznych. Trzeba zatem rozważyć, w jakim stopniu warunki kształcenia wyznaczane są przez profil szkoły wyższej, charakterystykę kierunku studiów oraz plan studiów (por. WOJCIECHOWSKI 2000).

\section{CELE I PLANY KSZTAŁCENIA W ZAKRESIE NAUK EKONOMICZNYCH NA KIERUNKU „TURYSTYKA I REKREACJA” NA UCZELNI NIEMAJACEEJ PROFILU EKONOMICZNEGO}

Profil szkoły wyższej można analizować pod względem formalnym, wskazując typ uczelni, bądź merytorycznym - odwołując się do jej misji oraz związanych z jej realizacją celów krótko- i długookresowych (SZCZECHOWICZ 2014). W ten sposób AWF w Krakowie należy uznać za uczelnię publiczną, akademicką (Statut AWF Kraków 2015), której specyfika ujawnia się przez przedmiot realizowanej dydaktyki i nauki, związany z obszarem nauk o kulturze fizycznej. Choć jej zadania dydaktyczne i naukowe obejmują przede wszystkim przyrodnicze i humanistyczne podstawy wychowania fizycznego, sportu, rehabilitacji oraz turystyki i rekreacji, to obszary dydaktyki i nauki obejmują też kwestie organizacji sposobów zaspokajania potrzeb uczestników kultury fizycznej. Uzewnętrznia się to w szczególności na Wydziale Turystyki i Rekreacji (WTiR), przez co uzasadnia włączanie w proces kształcenia studentów efektów wpisujących się $\mathrm{w}$ przedmiot nauk ekonomicznych.

Dla kierunku "turystyka i rekreacja” realizowanym na WTiR obrano profil ogólnoakademicki - zarówno w ramach I, jak i II stopnia studiów; to sprawia, że proces kształcenia winien zawierać relatywnie szerokie spektrum zagadnień odnoszących się do powziętego przedmiotu poznania. Przedmiotem tym jest turystyka i rekreacja, rozumiane w kategoriach aktywności przestrzennej i fizycznej człowieka. Przedmiot ten ma charakter interdyscyplinarny, dlatego kierunek został umiejscowiony $\mathrm{w}$ kilku obszarach kształcenia. Jako wiodący obrano obszar nauk medycznych, nauk o zdrowiu i nauk o kulturze fizycznej, a jako obszary uzupełniające - $\mathrm{z}$ uwagi na interakcje międzyludzkie i środowiskowe, które są nieodłącznym elementem aktywności turystycznej i rekreacyjnej człowieka - nauki społeczne, przyrodnicze i humanistyczne. Przyjęto, że zjawiska turystyki i rekreacji są rozpatrywane $\mathrm{z}$ punktu widzenia potrzeb oraz możliwości jednostki, a wszelkie odwołania do dziedzin nauki pozostających poza obszarem kultury fizycznej winny być tej perspektywie podporządkowane (Opis kierunkowych efektów kształcenia dla studiów I stopnia 2012). W przypadku studiów II stopnia większą wagę przyłożono do perspektywy społecznej, stawiając za cel przygotowanie absolwentów do odgrywania ról kreacyjnych i kierowniczych. Dlatego w zbiorze oczekiwanych efektów w zakresie kompetencji społecznych wprowadzono postulat przedsiębiorczości (Opis kierunkowych efektów ksztatcenia dla studiów II stopnia 2012).

Wszystko to wskazuje na pomocniczą rolę nauk ekonomicznych w kształceniu studentów na kierunku "turystyka i rekreacja" realizowanym w krakowskiej AWF - co odróżnia tę uczelnię od szkól ekonomicznych przygotowujących absolwentów do pracy w branży turystycznej/rekreacyjnej. Znajduje to wyraz w strukturze zakładanych kierunkowych efektów kształcenia, w której efekty wpisujące się w obszar nauk ekonomicznych mają niewielki udział. Dotyczą one na studiach I stopnia zdobycia podstawowej wiedzy o turystyce i rekreacji jako gałęzi gospodarki, poznania zasad tworzenia i rozwoju przedsiębiorstw turystycznych i rekreacyjnych oraz przyswojenia podstaw 
zarządzania i funkcjonowania tego typu podmiotów. W ślad za tym winny zostać wypracowane umiejętności interpretowania zjawisk gospodarczych zachodzaccych w sferze turystyki i rekreacji, przygotowania analizy ekonomicznej przedsięwzięcia z zakresu turystyki i rekreacji oraz wdrażania funkcji zarządzania w organizacji (Opis kierunkowych efektów kształcenia dla studiów I stopnia 2012). Na studiach II stopnia postulowane efekty odnoszą się zwłaszcza do poznania zasad formułowania strategii umożliwiających przedsiębiorcom efektywne świadczenie dóbr i usług zaspokajających potrzeby związane $\mathrm{z}$ turystyką i rekreacja, ale także do wiedzy dotyczaccej gospodarowania przestrzenią oraz polityki państwa w sferze turystyki i rekreacji. Na fundamencie tej wiedzy winny zostać wypracowane umiejętności organizowania własnej firmy turystycznej lub rekreacyjnej, poprzez zgromadzenie niezbędnych zasobów oraz skuteczne i efektywne zarządzanie nimi, w tym prawidłowe posługiwanie się instrumentami marketingu (Opis kierunkowych efektów kształcenia dla studiów II stopnia 2012).

To z kolei przekłada się na plan studiów, który uściśla szczegółowe warunki realizacji przedmiotów. Na studiach I stopnia realizowany jest moduł przedmiotów z zakresu nauk ekonomicznych, którego charakterystykę zebrano $\mathrm{w}$ tab. 1 .

Tab. 1. Wykaz przedmiotów realizowanych w ramach modułu ekonomicznego na kierunku ,turystyka i rekreacja” w AWF w Krakowie na studiach I stopnia

\begin{tabular}{|c|l|c|c|}
\hline Lp. & \multicolumn{1}{|c|}{ Przedmiot } & Semestr & $\begin{array}{c}\text { Liczba } \\
\text { godzin }\end{array}$ \\
\hline 1 & Ekonomia & 1 & 60 \\
\hline 2 & Ekonomika turystyki i rekreacji & 2 & 45 \\
\hline 3 & Zarządzanie & 3 & 60 \\
\hline 4 & $\begin{array}{l}\text { Marketing usług turystycznych } \\
\text { i rekreacyjnch }\end{array}$ & 3 & 45 \\
\hline 5 & Podstawy rachunkowości & 3 & 45 \\
\hline Suma godzin 255
\end{tabular}

Źródło: opracowanie własne na podstawie planu studiów (www.awf.krakow.pl).

Tab. 2. Wykaz przedmiotów realizowanych w ramach modułu ekonomicznego na kierunku "turystyka i rekreacja” w AWF w Krakowie na studiach II stopnia

\begin{tabular}{|c|l|c|c|}
\hline Lp. & \multicolumn{1}{|c|}{ Przedmiot } & Semestr & $\begin{array}{c}\text { Liczba } \\
\text { godzin }\end{array}$ \\
\hline 1 & $\begin{array}{l}\text { Zarządzanie przedsiębiorstwem } \\
\text { turystycznym }\end{array}$ & 2 & 60 \\
\hline 2 & Polityka turystyczna i rekreacyjna & 3 & 60 \\
\hline \multicolumn{2}{|l}{ Suma godzin 120 }
\end{tabular}

Źródło: opracowanie własne na podstawie planu studiów (www.awf.krakow.pl).
W ramach studiów II stopnia centralne miejsce w kształceniu z zakresu nauk ekonomicznych zajmuja natomiast: "Zarządzanie przedsiębiorstwem turystycznym" i „Polityka turystyczna i rekreacyjna” (tab. 2).

W tab. 2 przedstawiono wyłącznie przedmioty obowiązujące wszystkich studentów. Wiele treści wpisujących się w interesujący nas obszar nauk jest zawartych w programach przedmiotów realizowanych w ramach specjalności - tak na studiach I, jak i II stopnia. Nie prezentujac charakterystyki takich przedmiotów w dalszej części opracowania przedstawiono tylko te informacje, które są ważne z punktu widzenia poszukiwania odpowiedzi na podstawione pytania badawcze; ograniczono się przy tym do wybranych przedmiotów.

\section{PROGRAMY NAUCZANIA PRZEDMIOTÓW Z ZAKRESU NAUK EKONOMICZNYCH: OD REALIZACJI STANDARDÓW KSZTAŁCENIA DO INTEGRACJI TREŚCI}

Nauczanie przedmiotów wchodzących w zakres nauk ekonomicznych w ramach kierunku "turystyka i rekreacja" na przełomie XX i XXI w. było podporządkowane obowiązującym wówczas standardom kształcenia. Narzucały one planowane do osiągnięcia cele i związane $z$ tym treści programowe. Mimo to szkoły wyższe zachowywały pewną swobodę jeśli chodzi o dobór szczegółowych treści wykładów i ćwiczeń, a także metod przekazywania studentom wiadomości, wypracowywania u nich umiejętności i kompetencji. Dlatego programy nauczania przedmiotów ekonomicznych w różnych szkołach wyższych na interesującym nas kierunku nie były jednolite, a i w samej krakowskiej AWF wraz z upływem czasu były modyfikowane. $\mathrm{W}$ końcu lat 90 . XX w. w ramach przedmiotu „Ekonomia” wykłady były poświęcone zagadnieniom makro-, a ćwiczenia mikroekonomicznym (Skrócony program nauczania 1998). Uzasadnienia takiego rozgraniczenia treści upatrywano $\mathrm{w}$ tym, że to mikroekonomia bezpośrednio wiąże się $\mathrm{z}$ funkcjonowaniem rynków i przedsiębiorstw, które zaspokajają potrzeby społeczne $\mathrm{w}$ zakresie turystyki i rekreacji.

Zmiana przedstawionego podejścia do realizacji przedmiotu nastąpiła w 2007 r., kiedy przyjęto tradycyjny układ, w którym wykłady poświęcone były prezentacji wiadomości z zakresu makro- oraz mikroekonomii, a ćwiczenia - dyskusji i realizacji zadań zmierzających do przyswojenia sobie przez studentów tych wiadomości, a także wypracowaniu umiejętności praktycznego ich wykorzystania. Opracowano konspekty poszczególnych jednostek zajęć, przyjmując 
jednolity sposób organizacji ćwiczeń przez wszystkich prowadzących; dla każdych ćwiczeń przygotowano zestawy zadań do rozwiązywania podczas zajęć, które nawiązywały do poprzedzającego dane ćwiczenia wykładu, a także opracowano treści zadań analitycznych, które studenci wykonywali w zespołach i prezentowali podczas ćwiczeń. W rezultacie przyjęcia tego porządku zajęć konieczne okazało się ograniczenie przekazywanych studentom wiadomości.

Jakkolwiek przedstawioną zmianę rozkładu treści pomiędzy wykłady i ćwiczenia, wraz z rokrocznie dopracowywanymi materiałami do ćwiczeń, należy ocenić pozytywnie, to dydaktyka w zakresie nauk ekonomicznych w krakowskiej uczelni wciąż napotyka ważkie problemy. Zwraca uwagę niewielka - w stosunku do szkół wyższych ekonomicznych - liczba godzin przeznaczona na nauczanie podstaw ekonomii, a także niedostatek podręczników w pełni dostosowanych do tych warunków. O ile bowiem na uczelniach ekonomicznych nauczanie to obejmuje tradycyjnie dwa przedmioty, tj. mikro- i makroekonomię, $\mathrm{z}$ których każdy realizowany jest $\mathrm{w}$ wymiarze minimum 60 godzin, to w przypadku akademii wychowania fizycznego nauczanie zamyka się najczęściej w liczbie 60 godzin przewidzianych na prezentację podstaw ekonomii w takim stopniu, aby mogły być one podstawą kształcenia kierunkowego. Ponadto problematyczne pozostaje rozgraniczenie treści podstawowych (ekonomia) i kierunkowych (ekonomika turystyki i rekreacji) - szczególnie w kontekście celu operacyjnego procesu bolońskiego, jakim jest rozwój kształcenia interdyscyplinarnego (Skrócony program nauczania 1998). Choć bowiem podejście takie jest uzasadnione w kształceniu ekonomistów, to w warunkach realizacji zajęć na kierunku, którego profil sytuuje zagadnienia ekonomiczne $\mathrm{w}$ grupie treści uzupełniających może ono nie być $w$ pełni efektywne. W tym drugim przypadku studenci nie tylko nie przedkładają perspektywy ekonomicznej postrzegania turystyki i rekreacji, nad perspektywę aksjologiczno-behawioralną, ale niekiedy też nie są dostatecznie przygotowani do przyjęcia spojrzenia bazującego na modelowaniu rzeczywistych obiektów i zjawisk; w szczególności dlatego, że ekonomia - jako przedmiot kształcenia ogólnego - wykładana jest już w pierwszym semestrze studiów licencjackich.

Wśród kierunków doskonalenia programów nauczania podstaw ekonomii studentów krakowskiej AWF pojawiła się idea połączenia $w$ jeden dwusemestralny przedmiot treści, które w dotychczasowym systemie kształcenia przekazywane są w ramach „Ekonomii” oraz "Ekonomiki turystyki i rekreacji”. Integracja taka miałaby umożliwić na stałe łączenie tego, co ogólne (podstawowa wiedza ekonomiczna) z tym, co szczegółowe, tj. odzwierciedlające specyfikę ważnej części sektora usług, do którego zalicza się turystykę i rekreację jako dziedzinę gospodarowania. Innymi słowy, chodziłoby o poszukiwanie odpowiedzi na często rodzące się wśród studentów pytanie: A jak ta ogólna wiedza ekonomiczna ma się do tej, którą otrzymuję studiując podstawy turystyki i rekreacji? W ślad za tą ideą finalizowane są prace nad programem przedmiotu, który łączyłby w sobie prezentację podstawowych zagadnień mikro-, mezo- i makroekonomii z ich bieżącą egzemplifikacją na gruncie turystyki i rekreacji, a także prace nad tego typu podręcznikiem.

Przyswojenie sobie przez studentów wiedzy ekonomicznej pozostaje podstawą dalszej edukacji w zakresie zarządzania, marketingu i rachunkowości. Największe zmiany w tym zbiorze przedmiotów dokonano dla programu nauczania marketingu. W momencie likwidacji standardów kształcenia „Marketing usług turystycznych i rekreacyjnych" przeniesiono na studia I stopnia, aby uzupełnić moduł ekonomiczny o pomijane w nim dotąd, na tym etapie kształcenia, spojrzenie na działalność gospodarczą uwzględniające w sposób pierwszoplanowy potrzeby i pragnienia konsumentów. Odstąpiono zarazem od tradycyjnego sposobu przekazywania wiadomości marketingowych na rzecz przyjęcia perspektywy planowania marketingowego - uzasadniając to faktem, że marketing jest tak dyscypliną nauk ekonomicznych, jak i praktyką funkcjonowania przedsiębiorstw (WIKTOR 2002). Wykład poświęcano odtąd prezentacji istoty marketingowego podejścia do zaspokajania potrzeb i pragnień konsumentów oraz kolejnych etapów planowania marketingowego. Ćwiczenia są zdominowane przez prezentacje przez studentów kolejnych części planów marketingowych, które są przez nich sukcesywnie przygotowywane w ramach pracy własnej. I w tym przypadku wiedza ogólnomarketingowa jest zatem od razu przenoszona na grunt specjalistycznych zainteresowań studentów, co pozostaje w zgodzie $\mathrm{z}$ wysuwanym przez samych studentów postulatem łączenia w nauczaniu marketingu teorii z praktyką (KOLNY, MACIEJOWSKI 2002).

\section{METODY NAUCZANIA PRZEDMIOTÓW Z ZAKRESU NAUK EKONOMICZNYCH: OD STANDARDOWYCH ZADAŃ ZESPOŁOWYCH DO PROBLEMOWYCH ZADAŃ INDYWIDUALNYCH}

Zmiany sposobu organizacji przedstawionych przedmiotów nie ograniczały się do kwestii programowych. Wraz z nimi modyfikowano metody nauczania - mając na uwadze specyfikę poszczególnych przedmiotów, merytoryczne związki zachodzące pomiędzy nimi oraz ich porządek wynikający z planu studiów. 
Dlatego przyjęto założenie, że początkowy kontakt studentów z ekonomią, dokonujący się w ramach wykładu z tak zatytułowanego przedmiotu, może być wzbogacony jedynie o dyskusję nad treścią poszczególnych wykładów oraz rozwiązywanie zadań wymagających nie kreatywności, a przyswojenia elementarnych umiejętności analizowania, interpretowania i przetwarzania danych ekonomicznych. Dla realizacji ćwiczeń przyjęto zatem formę audytoryjną (KALISZEWSKA, KLASIŃSKA 2008), którą wdrożono przez opracowanie jednolitego sposobu organizacji zajęć, w którym dla każdej jednostki ćwiczeń przygotowano zestaw zadań interpretacyjnych i obliczeniowych. Niektóre z zadań są rozwiązywane indywidualnie, inne zespołowo; każdorazowo studenci są oceniani z pracy wykonywanej podczas ćwiczeń. Testowano różne sposoby dystrybuowania studentom tych zadań: zarówno dostarczanie ich podczas zajęć, co pozwalało oceniać bieżącą pracę studentów, jak i przesyłanie ich z wyprzedzeniem, co pozwalało studentom przygotować się do zajęć.

O ile sens przedkładania studentom zestawów typowych dla poszczególnych tematów zadań interpretacyjno-obliczeniowych wynikał z konieczności wypracowania i utrwalenia elementarnych umiejętności operowania danymi ekonomicznymi, to część każdych ćwiczeń poświęcano na zespołowe zadania analityczne. Na każde ćwiczenia 3-osobowy zespół opracowywał temat, który wymagał samodzielnego wyszukania w statystyce publicznej danych empirycznych, a następnie poddania tych danych analizie wedle podanych wytycznych, przypisanych indywidualnie do każdej osoby wchodzącej w skład zespołu. Zadania te korespondują $z$ tematami zajęć, a ich prezentacja jest połączona $z$ moderowaną przez nauczyciela dyskusją. Wszystko to stwarza, w strukturze ćwiczeń, układ zadań, które pozwalają zarówno na utrwalenie wiedzy wyniesionej z wykładów, jak i kontrolę umiejętności jej wykorzystania.

Podobny zestaw metod jest stosowany w ramach "Ekonomiki turystyki i rekreacji”, przy czym zadania stawiane studentom służą w mniejszym stopniu opanowaniu umiejętności analitycznych, a w większym - poznaniu charakterystyki turystyki i rekreacji jako obszaru prowadzenia działalności gospodarczej; w związku z tym zadania te bazują już tylko na danych empirycznych. Równocześnie w ramach tego przedmiotu stopniowo rozwijany jest system różnicowania form aktywności studentów, zorientowany na poszerzenie ich możliwości wyboru o zadania podejmowane $\mathrm{z}$ uwzględnieniem własnych preferencji. Docelowo obejmować ma on również analogiczne do występujących w ramach „Ekonomii" zespołowe zadania analityczne, które aktualnie przybrały charakter prezentacji wniosków z lektury dokumentów źródłowych, przypisanych do poszczególnych jednostek ćwiczeń.

Doświadczenia płynące $\mathrm{z}$ implementacji przedstawionego sposobu organizacji pracy podczas ćwiczeń wskazują, że pozwala on podtrzymać zainteresowanie studentów treścią zajęć i wspomaga ich aktywność. Studenci stają bowiem przed koniecznością wykonywania istotnie różnych form zadań: począwszy od wysłuchania prelegentów, którzy w twórczej formie przywołują temat poprzednich zajęć, przez dyskusję, aż po przywołanie nowego tematu oraz rozwiązywanie związanych z tym zadań.

Poziom trudności zadań wzrasta na dalszym etapie kształcenia - zgodnie z zasadą „od prostego, do złożonego" (zob. KUPISIEWICZ 2012). Wówczas zakłada się, że studenci potrafią już opisywać zjawiska gospodarcze pozyskując, interpretując i przetwarzając ogólnodostępne dane i są przygotowani do realizacji zadań wymagających większej samodzielności, a nawet - kreatywności. Dlatego program nauczania "Marketingu usług turystycznych i rekreacyjnych" przewiduje pracę projektową, polegającą na przygotowywaniu planów marketingowych. To zadanie, z uwagi na wysoki stopień złożoności, jest podzielone na wyraźnie wskazane zadania cząstkowe, rozłożone na cały semestr. Każdy student na pierwszych zajęciach otrzymuje informację o strukturze planu marketingowego, która jest szczegółowo omawiana podczas kolejnych wykładów i na tej podstawie samodzielnie przygotowuje i realizuje badania terenowe, przeprowadza segmentację rynku i opracowuje plan produktu, dystrybucji, promocji i ceny. Kolejne elementy planów studenci prezentują podczas ćwiczeń, gdzie są one poddane dyskusji grupowej, a ponadto dwa razy w semestrze składają w formie pisemnej plany cząstkowe, dzięki czemu otrzymują dokładną informację zwrotną o silnych i słabych stronach swojej pracy. Dokonuje się to $\mathrm{w}$ formie pisemnej i ustnej: nauczyciel przekazuje grupie na piśmie i omawia podczas zajęć ogólne uwagi wskazujące na typowe, powtarzające się błędy lub braki, a jednocześnie nanosi uwagi skierowane do poszczególnych studentów na ich prace. Studenci są też zachęcani, a niekiedy obligowani do bezpośredniego kontaktu z nauczycielem podczas dyżuru. Wszystko to wpisuje się w ideę dydaktyki zaangażowanej (BUK-CEGIEŁKA 2016), wykorzystywania aktywnych metod dydaktycznych (active learning) oraz uczenia się przez działanie (learning by doing) (BIAŁEK, CYRAN 2013).

Przygotowanie planu marketingowego przewidziano początkowo jako zadanie zespołowe, z uwagi na wysoki poziom złożoności tego zadania. Z czasem, $\mathrm{z}$ powodu realnych trudności $\mathrm{w}$ ocenie wkładu członków zespołu w efekt końcowy realizacji zadania - pomimo że każdy ze studentów odpowiadał za ści- 
śle określony fragment planu - przygotowanie planów zdecydowano się przydzielać jako zadanie indywidualne. Ułatwiło to ocenę pracy studentów, ale i pozwoliło na pewne zróżnicowanie stawianych im zadań - co objawiło się zacieśnianiem relacji ze studentami, którzy wykazują większe zdolności, a także chęci wykraczające poza poprawne wykonanie koniecznych zadań. Indywidualizacja zadania wynosi więc studenta do pozycji partnera $\mathrm{w}$,prawdziwym dialogu" z nauczycielem (por. CZERWIŃSKI 2008), który dokonuje się między równorzędnymi podmiotami działającymi na rzecz realizacji wspólnych celów (DENEK 2016). Pozwala to też na doskonalenie warsztatu pisarskiego studenta, co stanowi uzupełniający, lecz ważny efekt realizacji ćwiczeń (BIAŁEK, CYRAN 2013).

Pierwotnie dbano, aby w każdej grupie dziekańskiej były realizowane plany marketingowe związane z różnymi, charakterystycznymi dla turystyki i rekreacji rodzajami działalności gospodarczej, tj. działalności organizatorów turystyki, obiektów hotelarskich, ośrodków rekreacyjnych. Ostatecznie zrezygnowano z tego podejścia i obecnie każdy student może zaproponować interesujący go rodzaj przedsięwzięcia z zakresu szeroko pojętej turystyki/rekreacji. Pozwala to wyzwolić większe zainteresowanie studentów przydzielanymi im zadaniami, a osoby o nieujawnionych preferencjach zmusza do refleksji dotyczącej swojej przyszłej drogi zawodowej. Zarazem ułatwia to zarówno pracę ze studentem "zdolnym", jak i „słabym”.

Warto nadmienić, że studenci częściej proponują tematy związane $\mathrm{z}$ działalnością rekreacyjną, niż turystyczną, co jest wyrazem skupienia ich uwagi na zaspokajaniu potrzeb związanych $\mathrm{z}$ zagospodarowaniem czasu wolnego ludzi w miejscu ich zamieszkania (tab. 3).
Zestawione $w$ tab. 3 dane dotyczą 430 prac zaliczeniowych $\mathrm{z}$ trzech lat. $W$ strukturze tematów obieranych przez studentów dominują przedsiębiorstwa rekreacyjne usługowe, którym towarzyszy znaczący odsetek przedsiębiorstw turystycznych handlowych (organizatorzy turystyki) i usługowych (obiekty noclegowe). Struktura tematów jest względnie stabilna, ze średnim udziałem przedsiębiorstw rekreacyjnych usługowych na poziomie $73 \%$. W ramach szczegółowej tematyki w dwóch najbardziej znaczących grupach tych przedsiębiorstw, obejmujących łącznie prawie $50 \%$ prac, znajdują się firmy świadczące usługi instruktażu w zakresie rekreacji fizycznej (zwłaszcza zajęcia fitness i taneczne) oraz usługi udostępniania infrastruktury sportowo-rekreacyjnej i terenów zielonych (zwłaszcza kluby fitness i siłownie).

Ujawnione prawidłowości dotyczące struktury preferencji studentów, być może nie tylko krakowskiej AWF, są użyteczną przesłanką do programowania ich dalszego kształcenia. To ostatnie może się dokonać przez silniejsze akcentowanie na innych przedmiotach treści dotyczących rekreacji lub bardziej powszechne odwoływanie się do przykładów przedsięwzięć z tego zakresu (studia przypadków), ale również przez zmiany w zbiorze oferowanych na uczelni specjalności bądź podjęcie prac zmierzających do uruchomienia nowych kierunków studiów, także podyplomowych. Te zaś przemiany, być może, kierują akademie wychowania fizycznego $\mathrm{w}$ stronę silniejszej specjalizacji w zakresie kształcenia związanego właśnie z programowaniem i obsługą rekreacyjnych form zagospodarowania czasu wolnego - czego zasadność wskazywał już S. LISZEWSKI (2011).

Tab. 3. Struktura tematyki prac zaliczeniowych z przedmiotu "Marketing usług turystycznych i rekreacyjnych" na AWF Kraków (w procentach)

\begin{tabular}{|c|c|c|c|c|c|c|c|c|}
\hline \multirow[b]{2}{*}{$\begin{array}{l}\text { Rok } \\
\text { akad. }\end{array}$} & \multicolumn{5}{|c|}{ Przedsiębiorstwa rekreacyjne świadczące usługi } & \multicolumn{3}{|c|}{ Przedsiębiorstwa turystyczne } \\
\hline & $\begin{array}{l}\text { instruktażu } \\
\text { w zakresie } \\
\text { rekreacji } \\
\text { fizycznej } \\
\end{array}$ & $\begin{array}{c}\text { udostępniania } \\
\text { infrastruktury spor- } \\
\text { towo-rekreacyjnej } \\
\text { i terenów zielonych }\end{array}$ & $\begin{array}{c}\text { gastrono- } \\
\text { miczne dla } \\
\text { miesz- } \\
\text { kańców } \\
\end{array}$ & $\begin{array}{c}\text { odnowy } \\
\text { biologicznej } \\
\text { lub kosme- } \\
\text { tyczne } \\
\end{array}$ & $\begin{array}{l}\text { pozo- } \\
\text { stałe }\end{array}$ & $\begin{array}{c}\text { organi- } \\
\text { zatorzy } \\
\text { tury- } \\
\text { styki } \\
\end{array}$ & $\begin{array}{l}\text { świadczące } \\
\text { usługi } \\
\text { noclegowe }\end{array}$ & $\begin{array}{l}\text { pozo- } \\
\text { stałe }\end{array}$ \\
\hline $2014 / 15$ & 35 & 11 & 8 & 8 & 9 & 10 & 8 & 11 \\
\hline $2015 / 16$ & 36 & 16 & 8 & 8 & 6 & 18 & 3 & 7 \\
\hline $2016 / 17$ & 27 & 21 & 10 & 6 & 8 & 15 & 6 & 7 \\
\hline $\begin{array}{l}\text { Średnia } \\
\text { trzyletnia }\end{array}$ & 33 & 16 & 8 & 7 & 7 & 14 & 5 & 8 \\
\hline $\begin{array}{l}\text { Średnia } \\
\text { trzyletnia }\end{array}$ & \multicolumn{5}{|c|}{73} & \multicolumn{3}{|c|}{27} \\
\hline
\end{tabular}

Źródło: opracowanie własne. 


\section{PODSUMOWANIE}

Realizując cel niniejszego opracowania należy stwierdzić, że w działaniach podejmowanych przez uczelnie o profilu innym niż ekonomiczny na rzecz doskonalenia programów nauczania użyteczne wydaje się przyjęcie orientacji zapożyczonej $\mathrm{z}$ subdyscypliny marketingu relacji, traktującej studenta jako klienta, będącego partnerem $\mathrm{w}$ procesie długookresowej wymiany, ukierunkowanej - $\mathrm{w}$ tym wypadku - na poszerzanie wiedzy o rzeczywistości gospodarczej. Ponieważ przedmiotem wymiany są tu informacje, warunkiem przyjęcia takiego podejścia jest wdrażanie metod realizacji programów nauczania, które dzięki zastosowaniu zasad dydaktyki akademickiej, komunikacji społecznej, cybernetyki i ekonomii informacji, pozwolą na poprawę efektywności nauczania, a zarazem podkreślą specyficzny charakter uczelni nieekonomicznych - jako łączących elementy kształcenia ogólnego z zawodowym.

W ramach tak przyjętych założeń, w oparciu o doświadczenia, obserwację uczestniczącą i zebrane dane, można pokusić się o wskazanie głównych składowych takiej orientacji dydaktycznej. Powinna ona obejmować:

- sporządzanie aktualnych, autorskich materiałów dydaktycznych - od podręczników, poprzez skrypty, do zestawów ćwiczeniowych i zadań analitycznych;

- wielokanałowe budowanie relacji ze studentem z użyciem zarówno kontaktu bezpośredniego, jak i z wykorzystaniem dostępnych technologii informacyjno-komunikacyjnych (e-learning);

- różnicowanie relacji ze studentami „zdolnymi” i „słabymi";

- doskonalenie efektywności informacyjnych sprzężeń zwrotnych w relacji nauczyciel-student, z testowaniem różnych sposobów przekazywania informacji zwrotnej;

- wielokryterialną ocenę pracy studenta, zarówno w kategoriach ilościowych, jak i jakościowych, $z$ elementami samooceny.

Odpowiedzi na postawione we wprowadzeniu pytania szczegółowe można ująć w czterech punktach:

1. Uwarunkowania kształcenia w uczelni o profilu nieekonomicznym określają częściowo, ale nie determinują celów nauczania przedmiotów z zakresu nauk ekonomicznych, które powinny umiejętnie balansować między treściami ogólnoekonomicznymi a specjalizacyjnymi.

2. Efekty kształcenia dla przedmiotów z zakresu nauk ekonomicznych na uczelni o profilu nieekonomicznym stosowane w krakowskiej AWF zdają się być aktualne i adekwatne. Należy jedynie mieć na uwadze zmieniające się predyspozycje studentów, które nie tyle stymulują do zawężania zakresu akademickiego wymiaru kształcenia ekonomicznego, ile do doskonalenia warsztatu dydaktycznego nauczycieli.

3. Integracja treści kształcenia przedmiotów z zakresu nauk ekonomicznych może poprawić jakość kształcenia, uzasadniając zarówno dedukcyjne związki między przedmiotami ogólniejszymi i bardziej szczegółowymi, jak również sprzyjając kompleksowości, a zarazem koherencji procesu nauczania $w$ ramach kształcenia modułowego.

4. Uzgodnienie zbioru metod dydaktycznych $\mathrm{w}$ ramach całego modułu przedmiotów z zakresu nauk ekonomicznych jest możliwe i efektywne, co więcej - jest celowe. Wymaga jednakże pogłębionej analizy i doskonalenia metod i technik dydaktycznych stosowanych $\mathrm{w}$ ramach poszczególnych przedmiotów $\mathrm{w}$ powiązaniu z odpowiednią alokacją treści kształcenia.

Przyjęcie i zastosowanie $\mathrm{w}$ procesie dydaktycznym optyki marketingu relacji z punktu widzenia nauczycieli akademickich jest zadaniem wymagającym ze względu na koszty przyjęcia takiego systemu pracy. Trzeba jednak zaznaczyć, że efekty takiego podejścia do dydaktyki - choć nienatychmiastowe - są satysfakcjonujące dla obu stron, studentów i nauczycieli. Student zachęcony rzetelnością podejścia nauczyciela odwzajemnia się i wzbogaca powiązany z procesem dydaktycznym proces badań naukowych.

\section{PRZYPIS}

${ }^{1}$ Dla ścisłości dodajmy, że dany kierunek może mieć charakter wieloobszarowy.

\section{BIBLIOGRAFIA}

BIAŁEK N., CYRAN K., 2013, Aktywne metody dydaktyczne - subiektywne kompendium, [w:] Wykładowca doskonaty. Podręcznik nauczyciela akademickiego, Oficyna a Wolters Kluwer business, Warszawa, s. 140-157

BuK-CEGIEŁKA M., 2016, Metody i formy ksztatcenia studentów - orientacja w kierunku dydaktyki zaangażowanej, [w:] A. Karpińska, W. Wróblewska, K. Kowalczuk (red.), W kierunku edukacji akademickiej zorientowanej na studenta, Wyd. Adam Marszałek, Toruń, s. 85-95.

CHMIELECKA E., 2013, Proces boloński i krajowe ramy kwalifikacji dla szkolnictwa wyższego, „Studia BAS”, 3(35), s. 107-134.

CZERWIŃSKI K., 2008, Student jako partner w dialogu edukacyjnym - rzeczywistość czy utopia, [w:] A. Karpińska, W. Wróblewska, K. Kowalczuk (red.), Dylematy dydaktyki szkoty wyższej w dialogu i perspektywie, Trans Humana, Białystok, s. 185-194. 
DENEK K., 2016, Interakcja uczestników procesu kształcenia akademickiego, [w:] A. Karpińska, W. Wróblewska, K. Kowalczuk (red.), W kierunku edukacji akademickiej zorientowanej na studenta, Wyd. Adam Marszałek, Torun, s. 31-45.

KALISZEWSKA M., KLASIŃSKA B., 2008, Modernizowanie dydaktyki akademickiej: perspektywa systemologiczna, [w:] A. Karpińska, W. Wróblewska (red.), Dylematy dydaktyki szkoty wyższej $w$ dialogu i perspektywie, Trans Humana, Białystok, s. 138-149.

KOLNY B., MACIEJEWSKI G., 2002, Ocena form nauczania a oczekiwania wobec prowadzacych przedmioty marketingowe, [w:] Z. Kędzior (red.), Marketing w dydaktyce szkót wyższych - teraźniejszość i przyszłość, Centrum Badań i Ekspertyz AE w Katowicach, Katowice, s. 38-51.

KuPISIEWICZ Cz., 2012, Dydaktyka. Podręcznik akademicki, Impuls, Kraków.

LISZEWSKI S., 2011, Recenzja ksiażki Turystyka w ujęciu interdyscyplinarnym, pod red. J. Wyrzykowskiego, J. Maraka, wydanej przez Wyższą Szkołę Handlową we Wrocławiu, Wroclaw 2010, „Turyzm” 21/1-2, s. 75-78.

Opis kierunkowych efektów ksztatcenia dla studiów I stopnia - profil ogólnoakademicki, kierunek turystyka i rekreacja, 2012, Wydział Turystyki i Rekreacji, AWF, Kraków.

Opis kierunkowych efektów kształcenia dla studiów II stopnia - profil ogólnoakademicki, kierunek turystyka i rekreacja, 2012, Wydział Turystyki i Rekreacji, AWF, Kraków.

Polska Rama Kwalifikacji. Wiedza, umiejętności, kompetencje spoteczne, 2016, Instytut Badań Edukacyjnych, Warszawa.

Rozporzadzenie Ministra Nauki i Szkolnictwa Wyższego z 12 lipca 2007 r. w sprawie standardów ksztatcenia dla poszczególnych kierunków oraz poziomów ksztatcenia, a także trybu tworzenia i warunków, jakie musi spetniać uczelnia, by prowadzić studia międzykierunkowe oraz makrokierunki, Dz.U., nr 164, poz. 1166.
Skrócony program nauczania dla kierunku „turystyka i rekreacja - studia licencjackie - realizowany od roku akademickiego 1998/99 w Akademii Wychowania Fizycznego im. Bronistawa Czecha w Krakowie, AWF Kraków.

Standardy kształcenia dla kierunków: Turystyka i rekreacja. Załącznik nr 108 do Rozporządzenia Ministra Nauki i Szkolnictwa Wyższego z dnia 12 lipca 2007 r. w sprawie standardów kształcenia dla poszczególnych kierunków oraz poziomów ksztatcenia, a także trybu tworzenia $i$ warunków, jakie musi spetniać uczelnia, by prowadzić studia międzykierunkowe oraz makrokierunki, Dz.U., nr 164, poz. 1166.

Statut Akademii Wychowania Fizycznego im. Bronistawa Czecha w Krakowie, AWF, Kraków 2015.

SZCZECHOWICZ B., 2014, Dydaktyka marketingu branżowego w Akademii Wychowania Fizycznego w Krakowie, [w:] A. Czubała, P. Hadrian, J.W. Wiktor (red.), Marketing w 25-leciu gospodarki rynkowej w Polsce, PWE, Warszawa, s. 715-722.

WIKTOR J.W., 2002, Formy dydaktyki wspótczesnego marketingu. Wyzwania i uwarunkowania, [w:] Z. Kędzior (red.), Marketing w dydaktyce szkót wyższych - teraźniejszość i przyszłość, Centrum Badań i Ekspertyz AE w Katowicach, Katowice, s. 87-102.

WOJCIECHOWSKI T., 2000, Dydaktyka marketingu, http://forum akad.pl/archiwum/2000/09/17.html; 19.10.2013.

WRÓBLEWSKA W., 2008, Zmiany w ksztatceniu akademickim, [w:] A. Karpińska, W. Wróblewska (red.), Dylematy dydaktyki szkoty wyższej w dialogu i perspektywie, Trans Humana, Białystok, s. 14-21.

www.awf.krakow.pl; 09.06.2017.
Artykuł wpłyną: 12 listopada $2017 \mathrm{r}$. Zaakceptowano do druku: 18 grudnia $2017 \mathrm{r}$. 